\title{
Oxygen stable isotope composition of carbonate encrustations of two modern, widely distributed, morphologically different charophyte species
}

\author{
Eugeniusz Pronin $(\mathbb{D} \cdot$ Mariusz Pełechaty $\cdot$ Karina Apolinarska \\ Andrzej Pukacz
}

Received: 14 March 2017/Revised: 19 November 2017/Accepted: 21 November 2017/Published online: 29 November 2017

(C) The Author(s) 2017. This article is an open access publication

\begin{abstract}
Oxygen $\left(\delta^{18} \mathrm{O}\right)$ and carbon $\left(\delta^{13} \mathrm{C}\right)$ stable isotope analyses are among the standard methods applied in the studies of past environment, including climate. In lacustrine sediments, $\delta^{18} \mathrm{O}$ and $\delta^{13} \mathrm{C}$ values can be measured in various carbonates including charophyte encrustations. Application of the stable isotope record of lacustrine carbonates requires knowledge about the possibilities and limitations of the method. Thus, this study presents the oxygen stable isotope composition of carbonate encrustations precipitated by modern charophytes $\left(\delta^{18} \mathrm{O}_{\mathrm{CARB}}\right)$ and
\end{abstract}

Handling editor: Katya E. Kovalenko

Electronic supplementary material The online version of this article (https://doi.org/10.1007/s10750-017-3444-4) contains supplementary material, which is available to authorized users.

\section{E. Pronin $(\bowtie) \cdot$ M. Pełechaty}

Department of Hydrobiology, Faculty of Biology, Adam

Mickiewicz University, Umultowska 89, 61-614 Poznań,

Poland

e-mail: e.pronin@uw.edu.pl

M. Pełechaty

e-mail: mariusz.pelechaty@amu.edu.pl

Present Address:

E. Pronin

Department of Plant Ecology \& Environmental Conservation, Institute of Botany, Biological and Chemical Research Centre, Faculty of Biology, University of Warsaw, Żwirki i Wigury 101, 02-089 Warsaw, Poland of ambient waters $\left(\delta^{18} \mathrm{O}_{\text {WATER }}\right)$. The study objects were widely distributed and morphologically different charophyte species, large and branchy Chara tomentosa L. and small and slender Chara globularis Thuill. Each species was studied in five lakes located in western Poland, at three sites per lake. The study demonstrated that $\delta^{18} \mathrm{O}_{\mathrm{CARB}}$ values were similar for the two charophyte species and were lake-dependent. $\delta^{18} \mathrm{O}_{\mathrm{CARB}}$ and $\delta^{18} \mathrm{O}_{\mathrm{WATER}}$ relationships were also similar for the studied charophytes with carbonate encrustations ${ }^{18} \mathrm{O}$-depleted compared to ambient waters. The shift of mean $\delta^{18} \mathrm{O}$ values between $C$. tomentosa and C. globularis encrustations and ambient waters, $2 \%$ and $3.2 \%$, respectively, was evidenced in all studied lakes which may indicate potential applicability of $\delta^{18} \mathrm{O}_{\mathrm{CARB}}$ of the two species in paleolimnological studies.

\section{K. Apolinarska}

Institute of Geology, Faculty of Geographical and

Geological Sciences, Adam Mickiewicz University,

Krygowskiego 12, 61-680 Poznań, Poland

e-mail: karinaap@amu.edu.pl

\section{A. Pukacz}

Polish-German Research Institute, Collegium Polonicum, Adam Mickiewicz University in Poznań - European University Viadrina in Frankfurt/Oder, Kościuszki 1, 69-100 Słubice, Poland

e-mail: pukacz@europa-uni.de 
Keywords $\delta^{18} \mathrm{O} \cdot$ Isotope geochemistry $\cdot$ Chara tomentosa $\cdot$ Chara globularis $\cdot$ Lakes

\section{Introduction}

Charophytes, macroscopic green algae from the extant family Characeae (Charales, Charophyta), occur in different water environments all over the world except for Antarctic regions (e.g., Hutchinson, 1975; Wade, 1990). However, they prefer freshwater calcium-rich lakes with oligo- and mesotrophic waters (Krause, 1981) and inhabit both deep and shallow sites (e.g., Martin et al., 2003). Charophytes often form extensive underwater stands referred to as charophyte meadows. Covering large areas, charophytes considerably affect the properties of lake water (e.g., alkalinity and hardness, saturation with $\mathrm{O}_{2}$, and transparency). These macroalgae also affect the composition and structure of phyto- and zooplankton as well as other elements of water biocoenosis (Królikowska, 1997; KuczyńskaKippen, 2001; Kufel \& Kufel, 2002; Blindow et al., 2014; Pełechata et al., 2016).

Dense charophyte meadows greatly intensify carbonate precipitation and contribute to the accumulation of marl sediments in lakes (Kufel \& Kufel, 2002; Pentecost et al., 2006; Apolinarska et al., 2011; Pełechaty et al., 2013; Pukacz et al., 2016a). This capacity results from photosynthetic removal of $\mathrm{CO}_{2}$ from dissolved bicarbonates (McConnaughey, 1997) and leads to the precipitation of insoluble $\mathrm{CaCO}_{3}$ (mostly calcite) in the form of encrustations on the surface of charophyte thalli. Encrustation may account for $30-80 \%$ of the charophyte dry matter (Pentecost, 1984; Królikowska, 1997; Kufel \& Kufel, 2002; Urbaniak, 2010; Pełechaty et al., 2013; Pukacz et al., 2016b). In temperate climate, the calcification process in charophytes is the most intensive in summer months (Pentecost et al., 2006; Pełechaty et al., 2010); thus, we can assume that in this season the majority of stem carbonates are precipitated. Charophyte remnants can be preserved in lacustrine sediments serving as indicators of past environmental conditions. While calcified oospores of charophytes (gyrogonites) are usually well preserved (Becker et al., 2002; Gałka \& Sznel, 2013; Kołaczek et al., 2015), fossilized parts of thalli encrustations are found less frequently because they easily disaggregate after charophyte decay and as a fine-grained carbonates substantially contribute to sediment deposition (Pełechaty et al., 2013).

In studies of lake sediments, oospores and encrustations, among other aquatic plant macrofossils, are useful indicators of past ecological conditions at the site of sediment deposition (Croft, 1952; Anadón et al., 2000; Becker et al., 2002; Rutkowski et al., 2007; Apolinarska et al., 2011). Therefore, analysis of plant macrofossils is commonly applied in paleolimnological reconstructions (Hannon \& Gaillard, 1997; Bešta et al., 2009; Gałka \& Apolinarska, 2014; Kowalewski et al., 2016).

In addition to the above-mentioned direct application, carbonates precipitated and deposited in lake sediments by charophytes can also be applied in paleoreconstructions based on their carbon $\left(\delta^{13} \mathrm{C}\right)$ and oxygen $\left(\delta^{18} \mathrm{O}\right)$ stable isotope compositions (Anadón et al., 2000; von Grafenstein et al., 2000; Hammarlund et al., 2003; Apolinarska \& Hammarlund, 2009). Carbon and oxygen stable isotopes have long been recognized as tracers of organic and inorganic processes in lakes. $\delta^{13} \mathrm{C}$ values of DIC (dissolved inorganic carbon) are used as indicators of the trophic status of lakes (de Kluijver et al., 2014), whereas $\delta^{18} \mathrm{O}$ values of lake waters are among others used to estimate the evaporative loss in lakes (Skrzypek et al., 2015). Application of carbon isotopes in the studies of lake sediments includes the reconstruction of changes in lake productivity (Lehmann et al., 2004) and shifts in lake water level (Woszczyk et al., 2014). Oxygen isotopes are used to reconstruct past climates (Słowiński et al., 2017) and changes in water retention in lakes (Hammarlund et al., 2003). Carbon and oxygen stable isotope composition was measured in various autochthonous carbonates occurring within sediments, i.e., mollusc shells (Stuiver 1970; Szymanek et al., 2016), ostracod carapaces (Lauterbach et al., 2011), and marl produced by phytoplankton (Słowiński et al., 2017). An attempt has also been made to use Chara encrustations and oospores in the studies of postglacial lacustrine deposits (e.g. Apolinarska \& Hammarlund, 2009).

To reliably use the record of $\delta^{13} \mathrm{C}$ and $\delta^{18} \mathrm{O}$ in lacustrine carbonates, including charophyte carbonates, for paleoreconstructions, it is necessary to properly recognize the relations between the stable oxygen and carbon isotope composition of modern carbonates and $\delta^{18} \mathrm{O}$ in water and $\delta^{13} \mathrm{C}$ in DIC. The number of publications on the geochemistry of 
lake marl sediments formed by charophytes has been increasing in the past two decades. According to Coletta et al. (2001), oxygen and carbon stable isotope composition of carbonates precipitated on the charophyte thalli can record the environmental conditions of the time when the carbonates were precipitated. Moreover, the age gradient along the charophyte stem reflects seasonal changes in $\delta^{18} \mathrm{O}_{\text {WATER }}$ and $\delta^{13} \mathrm{C}_{\text {DIC }}$ (Pentecost et al., 2006 and references therein). Although carbon and oxygen stable isotope composition of carbonates precipitated on the charophyte thalli and oospores has already been discussed (Coletta et al., 2001; Andrews et al., 2004; Pentecost et al., 2006; Pełechaty et al., 2010; Rodrigo et al., 2016), studies comparing the isotopic values of different charophyte species are sparse (Apolinarska et al., 2016; Pronin et al., 2016). This had led us to the study of two common, morphologically different charophyte species: Chara tomentosa Linné 1753, which has a large thallus, and the small Chara globularis Thuillier 1799. Consequently, Chara tomentosa, developing numerous branches, forms large communities that are freely penetrated by ambient water. Chara globularis, a slender and densely growing species, forms very compact stands proximal to the lake bottom, which are less likely to be penetrated by water. As we have recently documented (Pronin et al., 2016), there exist sharp differences between these two species expressed in the $\delta^{13} \mathrm{C}$ values of their organic matter $\left(\delta^{13} \mathrm{C}_{\mathrm{ORG}}\right)$ and carbonate encrustations $\left(\delta^{13} \mathrm{C}_{\mathrm{CARB}}\right)$ but not in DIC of ambient water $\left(\delta^{13} \mathrm{C}_{\text {DIC }}\right)$. These differences can be attributed to different forms of growth and, thus, different ambient water layers utilized as a source of DIC for photosynthesis (Pronin et al., 2016). As a result, the species revealed contrasting trends in the shift between their $\delta^{13} \mathrm{C}_{\mathrm{CARB}}$ and $\delta^{13} \mathrm{C}_{\mathrm{DIC}}$. In addition, in one of the charophytes studied, namely in Chara tomentosa, the values of $\delta^{13} \mathrm{C}_{\text {DIC }}$ were positively correlated with those of $\delta^{13} \mathrm{C}_{\mathrm{ORG}}$ and $\delta^{13} \mathrm{C}_{\mathrm{CARB}}$.

Considering the above, the aim of this study was (i) to test whether $C$. tomentosa and $C$. globularis differ in the oxygen stable isotope composition of their carbonate encrustations $\left(\delta^{18} \mathrm{O}_{\mathrm{CARB}}\right)$ and the ambient water $\left(\delta^{18} \mathrm{O}_{\text {WATER }}\right)$ and (ii) to investigate whether the shifts between the $\delta^{18} \mathrm{O}_{\mathrm{CARB}}$ and $\delta^{18} \mathrm{O}_{\text {WATER }}$ values follow similar or different pattern in the studied charophytes. We hypothesized that the values of $\delta^{18} \mathrm{O}_{\mathrm{WATER}}$, related to lake conditions, are reflected in the $\delta^{18} \mathrm{O}_{\mathrm{CARB}}$ values of the studied species, whereas the shifts between the $\delta^{18} \mathrm{O}_{\mathrm{CARB}}$ and $\delta^{18} \mathrm{O}_{\text {WATER }}$ values are species-specific.

\section{Study lakes}

The stable isotope composition of $C$. tomentosa and $C$. globularis carbonates and ambient waters was studied in seven lakes located in western Poland, in Lubuskie Lake District: Złoty Potok, Niesłysz, Jasne, Męcko Duże, Malcz Południowy, and in Myśliborskie Lake District: Karskie Wielkie (Fig. 1, see also Pronin et al., 2016). In previous studies, the authors documented the presence of numerous lakes with well-developed charophyte meadows in the investigated area especially in Lubuskie and Myśliborskie Lake Districts (Pełechaty et al., 2007; Pukacz et al., 2014; Pełechaty et al., 2015). With the exception of slightly eutrophicated Lake Karskie Wielkie, the studied bodies of water are mesotrophic lakes with high water clarity and well-developed submerged vegetation, dominated by charophyte meadows. These features place the studied lakes in the Chara-lakes group (Pełechaty et al., 2007; Pukacz et al., 2014; Pełechaty et al., 2015; Pronin et al., 2016). They include both small and shallow polymictic lakes and large and deep stratified water bodies. The residence time of the water, strongly influencing its oxygen stable isotopic composition, varied from $0.5,2.8$, and 3.3 years in Lakes Malcz Południowy, Jasne, and Karskie Wielkie, respectively, to about 5 years in other lakes (no reliable data exist for Lake Męcko Duże) (Table 1; Pronin et al., 2016 and reference therein). For detailed description of the studied lakes and sites refer to Pronin et al. (2016).

\section{Field sampling}

Each species was studied in five lakes and at three sites in each lake in July 2012 (Pronin et al., 2016). This gives 15 study sites for $C$. tomentosa and 15 sites for $C$. globularis. The species co-occurred in three lakes (Męcko Duże, Karskie Wielkie, and Jasne) and each of them occurred separately in two other lakes $(C$. tomentosa-in lakes Niesłysz and Złoty Potok, $C$. globularis-in lakes Malcz Południowy and Pierwsze). Altogether, the study was performed in seven lakes (Fig. 1, Table 1). In all the lakes studied, the species formed extensive and compact charophyte 


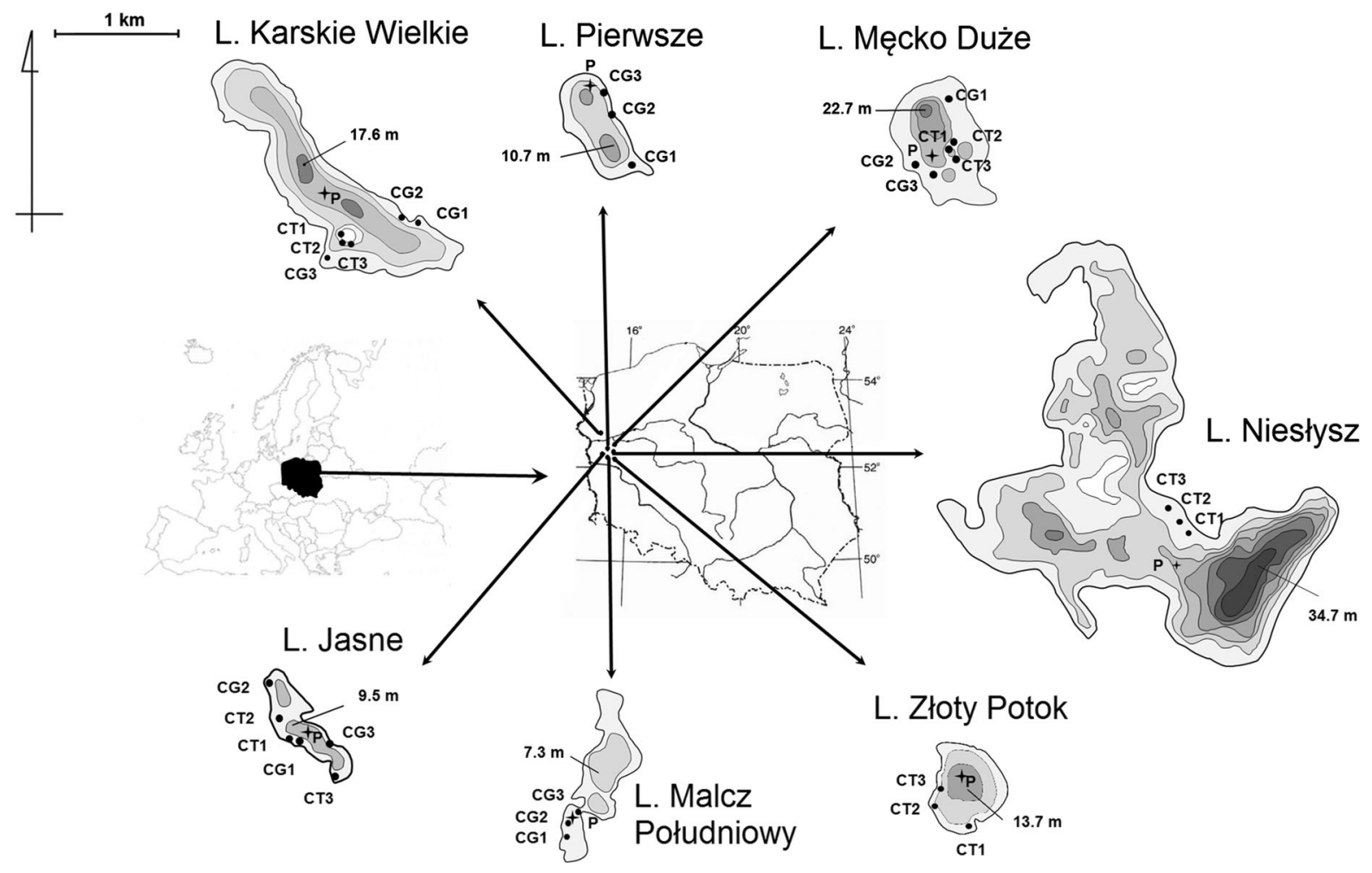

Fig. 1 Studied lakes and distribution of sampling sites. CT1-CT3—stands dominated by C. tomentosa, CG1-CG3—stands dominated by C. globularis, and $\mathrm{P}$-vegetation-free pelagic sites. Contour lines are at 5-m intervals

Table 1 Selected habitat characteristics of investigated lakes and the values of $\delta^{18} \mathrm{O}$ of pelagic water

\begin{tabular}{|c|c|c|c|c|c|c|c|}
\hline Lake & $\begin{array}{l}\text { Geographical } \\
\text { coordinates }\end{array}$ & $\begin{array}{l}\text { Area } \\
\text { (ha) }\end{array}$ & $\begin{array}{l}\text { Max. } \\
\text { depth (m) }\end{array}$ & $\begin{array}{l}\text { Mean } \\
\text { depth }(\mathrm{m})\end{array}$ & $\begin{array}{l}\text { Character } \\
\text { of flow }\end{array}$ & $\begin{array}{l}\text { Time of water } \\
\text { exchange }^{\mathrm{a}} \text { (years) }\end{array}$ & $\begin{array}{l}\delta^{18} \mathrm{O} \text { of pelagic water } \\
(\mathrm{V}-\mathrm{SMOW})\end{array}$ \\
\hline Męcko Duże $\mathrm{e}^{\mathrm{b}}$ & $\begin{array}{l}52^{\circ} 22^{\prime} 0^{\prime \prime} \mathrm{N} \\
15^{\circ} 11^{\prime} 2^{\prime \prime} \mathrm{E}\end{array}$ & 40.9 & 22.7 & 9.2 & Closed & n.d & -1.57 \\
\hline $\begin{array}{l}\text { Karskie } \\
\text { Wielkie }^{\text {b }}\end{array}$ & $\begin{array}{l}52^{\circ} 55^{\prime} 4^{\prime \prime} \mathrm{N} \\
15^{\circ} 04^{\prime} 8^{\prime \prime} \mathrm{E}\end{array}$ & 150 & 17.6 & 6.2 & Outflow & 3.3 & -3.53 \\
\hline Jasne $^{\mathrm{b}}$ & $\begin{array}{l}52^{\circ} 17^{\prime} 7^{\prime \prime} \mathrm{N} \\
15^{\circ} 03^{\prime} 06^{\prime \prime} \mathrm{E}\end{array}$ & 15.1 & 9.5 & 4.3 & Closed & 2.8 & -1.71 \\
\hline Niesłysz $^{\mathrm{b}}$ & $\begin{array}{l}52^{\circ} 13^{\prime} 9^{\prime \prime} \mathrm{N} \\
15^{\circ} 23^{\prime} 8^{\prime \prime} \mathrm{E}\end{array}$ & 486.2 & 34.7 & 7.8 & $\begin{array}{c}\text { Through } \\
\text { flow }\end{array}$ & 5 & -4.48 \\
\hline Złoty Potok ${ }^{\mathrm{b}}$ & $\begin{array}{l}52^{\circ} 13^{\prime} 0^{\prime \prime} \mathrm{N} \\
15^{\circ} 22^{\prime} 5^{\prime \prime} \mathrm{E}\end{array}$ & 32.8 & 13.7 & 5.9 & Closed & 5 & -4.25 \\
\hline $\begin{array}{l}\text { Malcz } \\
\text { Południowy }\end{array}$ & $\begin{array}{l}52^{\circ} 21^{\prime} 1^{\prime \prime} \mathrm{N} \\
15^{\circ} 13^{\prime} 3^{\prime \prime} \mathrm{E}\end{array}$ & 36.2 & 7.3 & 3.4 & $\begin{array}{l}\text { Through } \\
\text { flow }\end{array}$ & 0.5 & -2.31 \\
\hline Pierwsze $^{\mathrm{b}}$ & $\begin{array}{r}52^{\circ} 23^{\prime} 11^{\prime \prime} \mathrm{N} \\
15^{\circ} 09^{\prime} 18^{\prime \prime} \mathrm{E}\end{array}$ & 19.3 & 10.7 & 4.7 & Closed & 5.1 & -1.56 \\
\hline
\end{tabular}

Data sources: ${ }^{\mathrm{a}}$ Pronin et al. (2016), ${ }^{\mathrm{b} J a n ́ c z a k ~(1996) ~}$

stands. Slender and densely growing C. globularis formed compact meadows near the bottom sediments, at the depth of 3-4 m, while taller, thicker, and branched $C$. tomentosa formed less compact stands at depths between 2 and $3 \mathrm{~m}$, allowing waters from above the stand to penetrate into it more easily 
compared to C. globularis. At each site, 10 individual charophyte thalli from an area of $4 \mathrm{~m}^{2}$ were collected by diving. Prior to charophyte collection, water for isotopic analyses was sampled directly from above the charophyte stands using a bathometer, poured to a 10-ml glass septa test tube, and preserved with two drops of $\mathrm{HgCl}_{2}$ (Li \& Liu, 2011; Apolinarska et al., 2015; Pronin et al. 2016). Additionally, as a control sample, water for isotopic analyses was also sampled from one vegetation-free pelagic site in each lake.

\section{Laboratory work and analyses}

Air-dried thalli of ten charophyte individuals with calcite encrustations were homogenized using a mortar and pestle and constituted a single sample for each studied site. The samples were transferred to Eppendorf test tubes and, together with water samples, sent to the Isotope Dating and Environment Research Laboratory in Warsaw, Poland, for stable isotope analyses. In the laboratory, carbonates (on average $400 \mu \mathrm{g}$ of each sample) were dissolved in $100 \%$ phosphoric acid (density 1.9 ) at $75^{\circ} \mathrm{C}$ (McCrea, 1950), using a Kiel IV online carbonate preparation line connected to a ThermoFinnigan Delta + mass spectrometer. All values are reported as $\delta$ values in per mil relative to $\mathrm{V}$-PDB by assigning a $\delta^{18} \mathrm{O}$ value of $-2.20 \%$ to NBS19. The reproducibility was tested by replicate analysis of laboratory standards and was found to be better than $\pm 0.07 \%$.

The $\delta{ }^{18} \mathrm{O}$ values of the water were measured using a GasBench-II headspace autosampler connected to a Finnigan MAT 253 isotope ratio mass spectrometer (IRMS). To ensure the precision of the values reported as $\delta$ values in per mil relative to $\mathrm{V}$-SMOW, three international standards were measured: GISP $(24.76 \%$ to V-SMOW), USGS W6444 (-51.4\% to V-SMOW), and USGS W 67400 (- 1.97\% to V-SMOW) (Coplen et al., 2006). The reproducibility was tested by replicate analysis of laboratory standards and was found to be better than $\pm 0.25 \%$. Analytical procedures were described in detail in Apolinarska et al. (2015) and Pronin et al. (2016). The values of $\delta^{18} \mathrm{O}_{\text {WATER }}$ and $\delta^{18} \mathrm{O}_{\mathrm{CARB}}$, reported in this study for each studied species and each single site, are mean values of ten individuals collected in the field.

\section{Statistical analyses}

Since the empirical data distribution was inconsistent with the normal one, for most of the variables nonparametric tests were applied for the statistical data analyses. Therefore, the significance of differences between the tested species was checked using the Mann-Whitney $U$ test. The relationship between $\delta^{18} \mathrm{O}_{\mathrm{CARB}}$ and $\delta^{18} \mathrm{O}_{\text {WATER }}$ of the studied charophytes was tested using the Spearman rank R correlation. For the statistics applied, $P<0.05$ was regarded as statistically significant. Statistica 10 software (StatSoft Inc., Tulsa, OK, USA) was applied to the MannWhitney U test and Spearman correlation. To illustrate the relations between the values of stable oxygen and (comparatively) carbon isotope composition of charophyte carbonates and water sampled from above the studied Chara stands (separately for C. tomentosa and C. globularis), scatter diagrams were plotted. Furthermore, for the lakes where both charophyte species cooccurred (Lake Męcko Duże, Lake Karskie Wielkie, Lake Jasne), scatter diagrams were plotted to illustrate the differences between the $\delta^{13} \mathrm{C}_{\mathrm{CARB}}$ and $\delta^{18} \mathrm{O}_{\mathrm{CARB}}$ values and those of $\delta^{13} \mathrm{C}_{\text {DIC }}$ and $\delta^{18} \mathrm{O}_{\text {WATER }}$ above the studied stands and of pelagic water.

\section{Results}

Mean values of $\delta^{18} \mathrm{O}_{\mathrm{WATER}}$ in lakes varied from about - $1.50 \%$ (lakes: Męcko Duże, Malcz Południowy, Pierwsze) to about $-4.00 \%$ (Lake Karskie Wielkie) and about $-4.50 \%$ (Lake Niesłysz and Złoty Potok, Online Resource 1). Mean oxygen stable isotope values of $C$. tomentosa encrustations changed between - 6.11\%o in Lake Złoty Potok and - 3.14\%o in Lake Męcko Duże (Online Resource 1). The values measured in encrustations of $C$. globularis varied between - 6.28\%o in Lake Jasne and - 3.62\%o in Lake Męcko Duże (Online Resource 1).

Although differences in $\delta^{18} \mathrm{O}_{\text {WATER }}$ between the lakes studied were evidenced, differences between $\delta^{18} \mathrm{O}_{\mathrm{CARB}}$ and $\delta^{18} \mathrm{O}_{\text {WATER }}$ were comparable at all the sites and in all the lakes from which samples were collected for isotopic analyses (Online Resource 1). Carbonate encrustations of both charophyte species were ${ }^{18} \mathrm{O}$-depleted relative to $\delta^{18} \mathrm{O}$ values of ambient waters; however, the extent of ${ }^{18} \mathrm{O}$-depletion in $C$. 
globularis was greater compared to $C$. tomentosa (Online Resource 1, Fig. 2, Fig. 3).

The differences between oxygen stable isotope composition of carbonates of the charophyte encrustations $\left(\delta^{18} \mathrm{O}_{\mathrm{CARB}}\right)$ and ambient waters $\left(\delta^{18} \mathrm{O}_{\text {WATER }}\right)$ (Fig. 2) were statistically significant (Mann-Whitney $U$ test, $P<0.0006)$ in both studied species. Importantly, the differences in the $\delta^{18} \mathrm{O}_{\mathrm{CARB}}$ values between C. tomentosa and C. globularis were insignificant (Mann-Whitney $U$ test, $P>0.05$ ).

In contrast to $\delta^{18} \mathrm{O}_{\mathrm{CARB}}$ values, the values of $\delta^{18} \mathrm{O}_{\text {WATER }}$ significantly differed between the investigated species when all investigated lakes were considered together (Mann-Whitney $U$ test, $P<0.005)$. However, when the two species cooccurred in the same lake, no significant difference in $\delta^{18} \mathrm{O}_{\text {WATER }}$ between them was noted. Figures 3 and 4 show the differences between stable oxygen and carbon isotope composition of carbonates and ambient waters in all investigated lakes (Fig. 3) and in lakes where $C$. tomentosa and $C$. globularis co-occurred (Fig. 4). It is noteworthy that conversely to $\delta^{13} C_{\text {DIC }}$ and $\delta^{13} \mathrm{C}_{\mathrm{CARB}}$ values (Pronin et al., 2016), the difference between $\delta^{18} \mathrm{O}_{\text {WATER }}$ and $\delta^{18} \mathrm{O}_{\mathrm{CARB}}$ values revealed a similar trend for the two studied species (Figs. 2, 3, 4). Therefore, in each lake and at each sampling site, the water from above the charophyte stands was richer in ${ }^{18} \mathrm{O}$ compared to the carbonate encrustations of each of the studied species (Fig. 3a, b). The tendency described above is particularly evident in lakes in which both species co-occurred

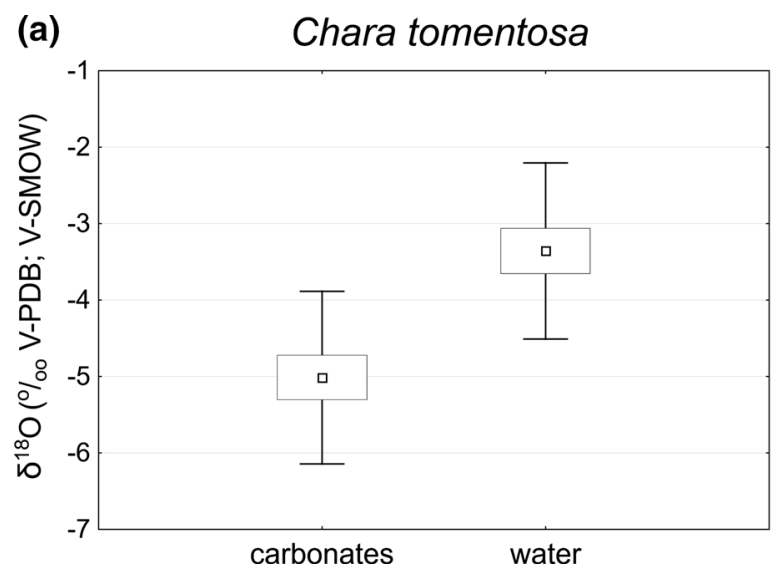

Fig. 2 Differences in oxygen stable isotope values between carbonates and water in a C. tomentosa and b C. globularis stands. For each species $N=15$; mean, 25-75\% mean $+\mathrm{SE}$ under similar conditions (Fig. 4a-c). In C. globularis, the differences between $\delta^{18} \mathrm{O}_{\mathrm{WATER}}$ and $\delta^{18} \mathrm{O}_{\mathrm{CARB}}$ values were greater than in $C$. tomentosa (mean \pm $\mathrm{SD}$; for C. globularis, $\delta^{18} \mathrm{O}_{\mathrm{CARB}}=-5.41 \pm 1.19 \%$; $\delta^{18} \mathrm{O}_{\text {WATER }}=-2.19 \pm 0.91 \%$, while for C. tomentosa $\quad \delta^{18} \mathrm{O}_{\mathrm{CARB}}=-5.01 \pm 1.13 \% ; \quad \delta^{18} \mathrm{O}_{\mathrm{WATER}}=$ $-3.36 \pm 1.15 \%$ ). The values of $\delta^{18} \mathrm{O}_{\text {WATER }}$ and $\delta^{18} \mathrm{O}_{\mathrm{CARB}}$ were highly and significantly correlated in both species (Fig. 5a, b) but the Spearman rank R correlation values were higher in the case of $C$. tomentosa stands.

\section{Discussion}

Oxygen stable isotope composition of lake water is dependent on the $\delta^{18} \mathrm{O}$ values of the waters supplying the lake (precipitation, surface, and groundwater) and the rate of water exchange in the basin (Leng \& Marshall, 2004 and references therein). The latter factor controls the degree to which the lake becomes ${ }^{18} \mathrm{O}$-enriched by evaporation. All the studied lakes were considerably ${ }^{18} \mathrm{O}$-enriched relative to local groundwater (- 9.2\%o, d'Obryn et al., 1997), indicating strong influence of evaporation on $\delta^{18} \mathrm{O}_{\text {WATER }}$ The degree of the evaporative enrichment in ${ }^{18} \mathrm{O}$ was lake-specific. Lakes Jasne, Pierwsze, and Męcko Duże, characterized by the highest $\delta^{18} \mathrm{O}$ values in waters $(-1.71,-1.56$, and $-1.57 \%$, respectively), are small and/or closed with long water retention (Table 1), and thus are prone to strong evaporation.

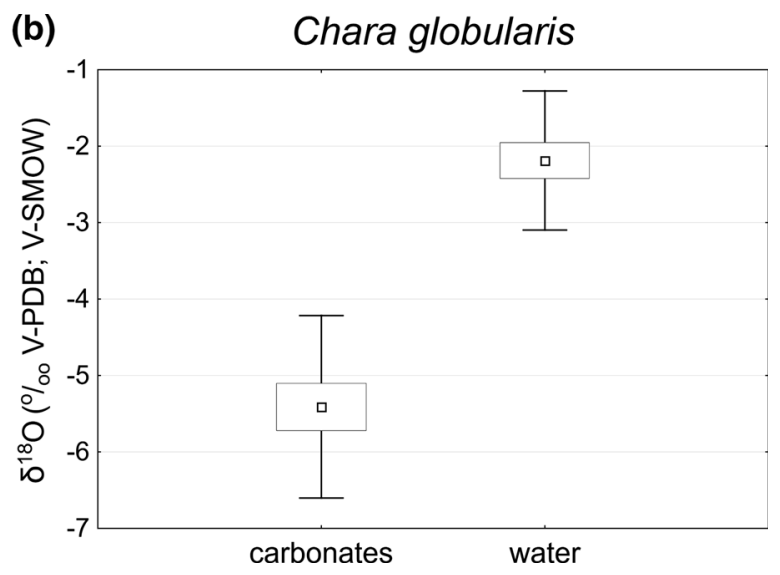

and mean +2 SD values are presented. For both species $P<0.001$ (Mann-Whitney $U$ test) 


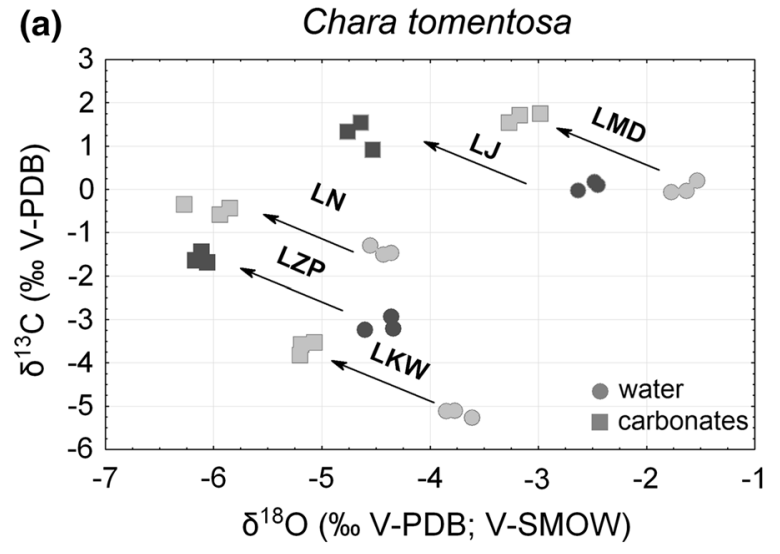

Fig. 3 The differences between stable isotope composition of carbonates and ambient waters in a Chara tomentosa and b Chara globularis stands. Both species are characterized by similar trends in $\delta^{18} \mathrm{O}$ values, whereas the opposite trend was evidenced for $\delta^{13} \mathrm{C}$, here presented only for comparison (for

Lake Malcz Południowy, although it has a throughflow character and thus $\delta^{18} \mathrm{O}$ values of its waters should be closer to $\delta^{18} \mathrm{O}$ values in local groundwater, is also relatively small and shallow and is characterized by intermediate $\delta^{18} \mathrm{O}$ values $(-2.31 \%$ ). Lakes Karskie Wielkie and Niesłysz, both big, deep, and throughflow lakes, are less ${ }^{18} \mathrm{O}$-enriched $(-3.53 \%$ o and $-4.48 \%$, respectively), as expected (based on Leng \& Marshall, 2004). Interestingly, $\delta^{18} \mathrm{O}$ values of waters in Lake Złoty Potok ( $-4.25 \%$ ), a closed lake with long water retention, are comparable to $\delta^{18} \mathrm{O}_{\text {WATER }}$ in the big and throughflow Lake Niesłysz. Considering the above data, we suggest that the supply of groundwater is important in the water budget of Lake Złoty Potok, which lowers $\delta^{18} \mathrm{O}_{\text {WATER }}$ values in the lake.

It seems important that the differences between $\delta^{18} \mathrm{O}_{\text {WATER }}$ and $\delta^{18} \mathrm{O}_{\mathrm{CARB}}$ values were concurrent in each studied lake and at each studied site, similarly to those of $\delta^{13} \mathrm{C}_{\text {DIC }}$ and $\delta^{13} \mathrm{C}_{\mathrm{CARB}}$ (compare Pronin et al. 2016). The factors controlling oxygen stable isotope composition of encrustations are thus considered to be species-specific, which we attempt to evidence below.

The differences between the values of $\delta^{18} \mathrm{O}_{\mathrm{CARB}}$ and $\delta^{18} \mathrm{O}_{\text {WATER }}$ for $C$. tomentosa in four out of the five studied lakes were less than $2 \%$ and only in Lake Jasne did they slightly exceed that value (Online Resource 1). Apolinarska et al. (2016) observed a comparable difference between the mean values of $\delta^{18} \mathrm{O}_{\mathrm{CARB}}$ for $C$. tomentosa and $\delta^{18} \mathrm{O}_{\mathrm{WATER}}$ in Lake

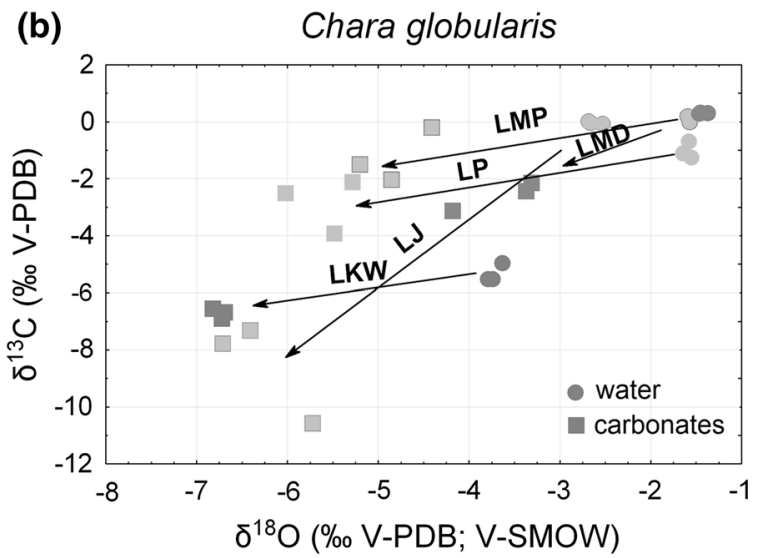

details please refer to Pronin et al., 2016). Lakes: LMD Lake Męcko Duże, $L J$ Lake Jasne, $L N$ Lake Niesłysz, $L Z P$ Lake Złoty Potok, $L K W$ Lake Karskie Wielkie, LMP Lake Malcz Południowy, $L P$ Lake Pierwsze; for each species $N=15$

Lednica, -5.20 and $-3.98 \%$, respectively. As assumed by Andrews et al. (2004), the shift in values between $\delta^{18} \mathrm{O}_{\text {WATER }}$ and $\delta^{18} \mathrm{O}_{\mathrm{CARB}}$, proving the precipitation of carbonate encrustation of charophytes in isotopic equilibrium with the surrounding water, is $1.5 \%$. However, due to the fact that our study did not cover the whole period when encrustations could have been precipitated, it is impossible to assert whether carbonate precipitation occurred in the condition of equilibrium with the water surrounding charophytes.

In the case of $C$. globularis (Fig. 4b), differences in values between $\delta^{18} \mathrm{O}_{\mathrm{CARB}}$ and $\delta^{18} \mathrm{O}_{\mathrm{WATER}}$ were much greater (mean: $3.2 \%$ ) and not as evenly distributed as in $C$. tomentosa. This may explain why a positive correlation between $\delta^{18} \mathrm{O}_{\mathrm{CARB}}$ and $\delta^{18} \mathrm{O}_{\text {WATER }}$, found for both the studied species (Fig. 5a, b), was considerably stronger for $C$. tomentosa (Fig. 5a). Because $C$. globularis was more ${ }^{18} \mathrm{O}$-depleted in all the studied lakes relative to ambient water than $C$. tomentosa, a common factor is considered to be responsible for the difference observed. Even greater difference between $\delta^{18} \mathrm{O}_{\text {WATER }}$ and $\delta^{18} \mathrm{O}_{\mathrm{CARB}}$ of $C$. globularis encrustations was reported by Huon \& Mojon (1994). In midJuly, the above values were $-2.83 \%$ and $-10.4 \%$, respectively. However, the great $7.75 \%$ o difference between the water and encrustation $\delta^{18} \mathrm{O}$ values may to some degree result from the partial drying up of the pond in July and strong evaporative ${ }^{18} \mathrm{O}$-enrichment in water observed by Huon \& Mojon (1994). Moreover, due to decreased water $\mathrm{pH}$ in mid-July, carbonates 

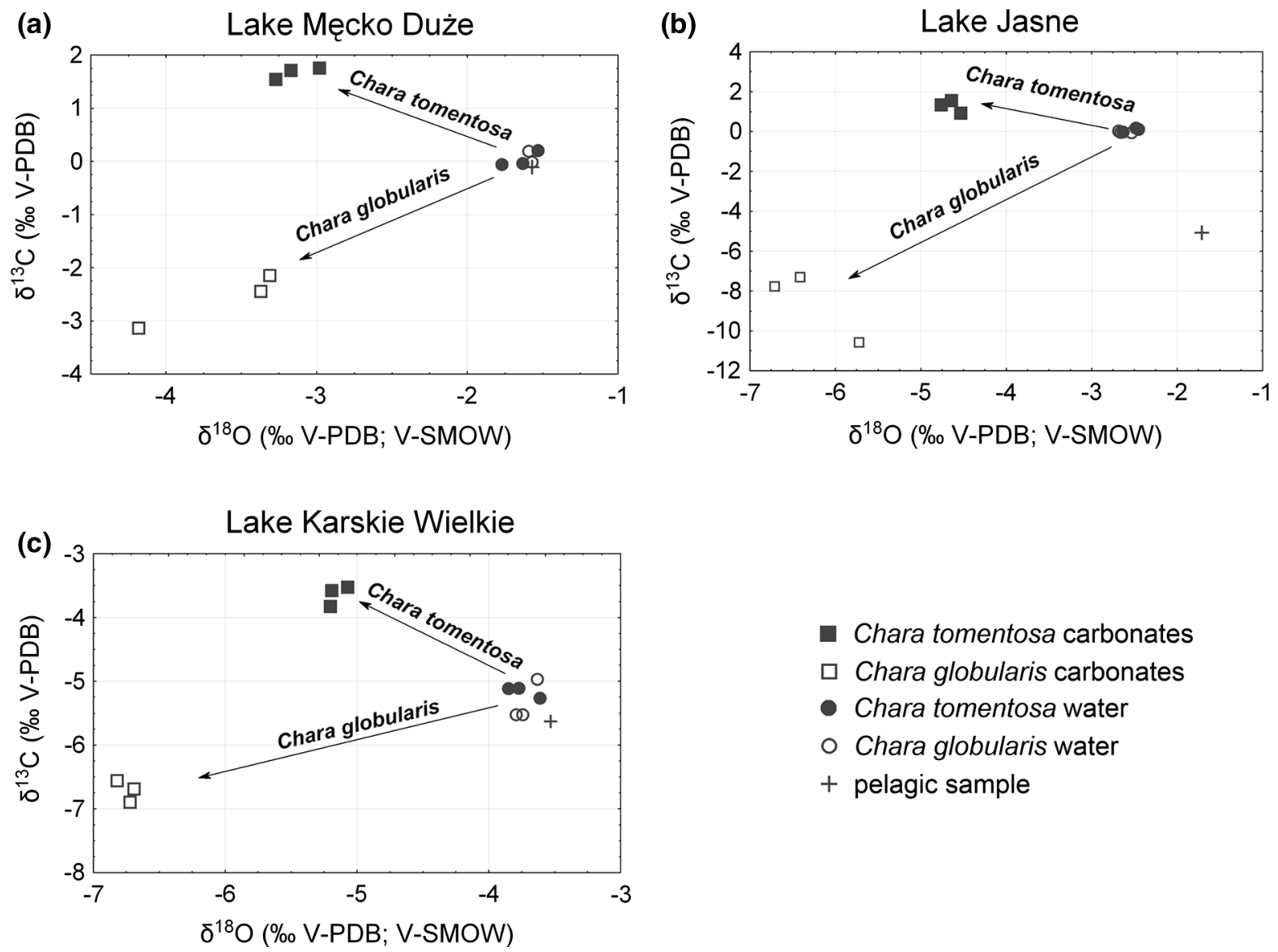

Fig. 4 The differences between stable isotope composition of carbonates and ambient waters in Chara tomentosa and Chara globularis stands co-occurring under similar conditions in the same lakes: a Lake Męcko Duże, b Lake Jasne, and c Lake

Karskie Wielkie. Additionally, pelagic sites were marked in each lake. For each species, $N=15$ in each studied lake. Comment to $\delta^{13} \mathrm{C}$ values as in Fig. 3

(a)

Chara tomentosa

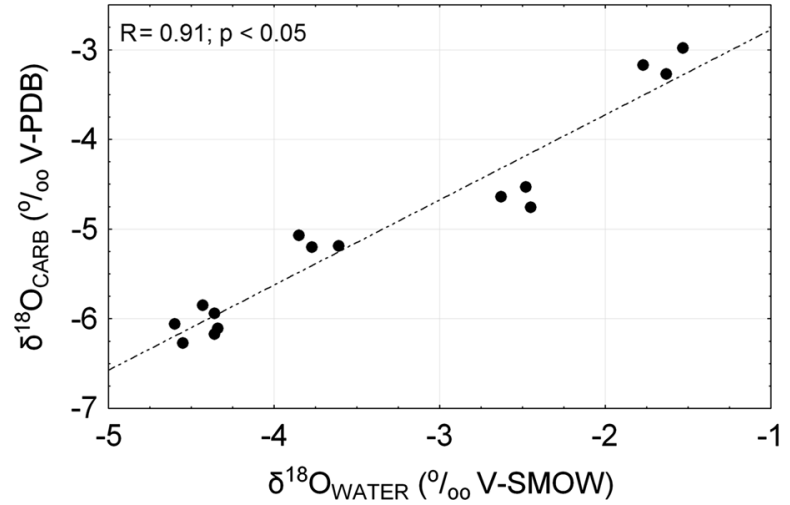

(b)

Chara tomentosa carbonates

口 Chara globularis carbonates

- Chara tomentosa water

- Chara globularis water

+ pelagic sample

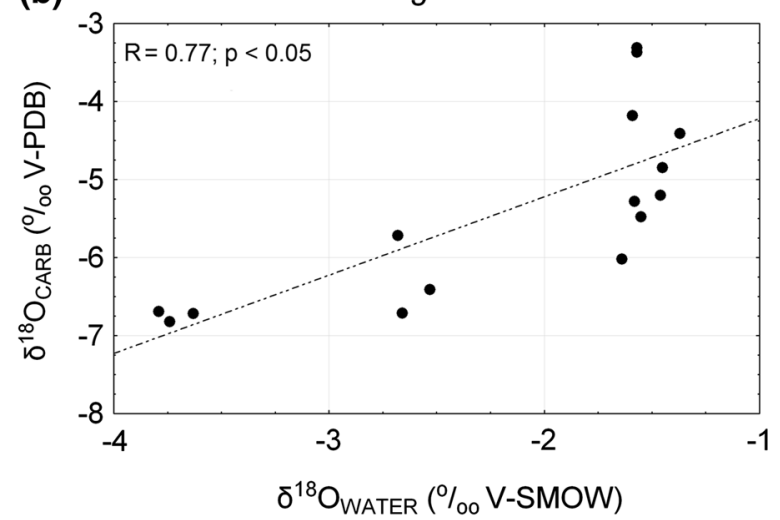

Fig. 5 Spearman $\mathrm{R}$ rank correlations between $\delta^{18} \mathrm{O}_{\mathrm{CARB}}$ and $\delta^{18} \mathrm{O}_{\mathrm{WATER}}$ values for a Chara tomentosa stands and $\mathbf{b}$ Chara globularis stands. For each species, $N=15$ 
were not precipitated at this final stage of the pond existence. Considering the oxygen stable isotope composition of water measured in mid-June, i.e., $-4.74 \%$ at $\mathrm{pH} 8.5$, the above discussed difference in $\delta^{18} \mathrm{O}$ values between water and encrustations decreases to $5.66 \%$, which is still greater than the value of $-3.2 \%$ observed in the present study. The influence of $\mathrm{pH}$ on the $\delta^{18} \mathrm{O}_{\mathrm{CARB}}$ values was addressed in Pentecost et al. (2006) study. However in that study, charophytes investigated by Pentecost et al. (2006) were derived also from a small pond which desiccated during the vegetative season. Progressive lowering of the water level in this study and continuous photosynthesis by charophytes resulted in strong increase of $\mathrm{pH}$. As a consequence, water $\mathrm{pH}$ reached values higher than 9 and the $\mathrm{CO}_{3}{ }^{2-}$ species that was present in water has influenced the $\delta^{18} \mathrm{O}$ values.

Although we performed our study at the peak of growing season when $\mathrm{pH}$ is expected to be the highest, the $\mathrm{pH}$ values were always lower than 9. Additionally, the differences of $\mathrm{pH}$ were negligible between the sites in each lake as well as between investigated lakes (see Table 3 in Pronin et al., 2016). Therefore, we assumed that the presence of $\mathrm{CO}_{3}{ }^{2-}$ species of carbon was negligible (for details please refer to Pronin et al., 2016). To justify our standpoint, we attach the model of carbon speciation according to $\mathrm{pH}$ (MINEQL 4.6 software, Environmental Research Software, Hallowell, ME, USA; Online Resource 2). It clearly points to bicarbonate ions as a dominant DIC form in the studied lake. All the above allowed us to assume that in case of our study the $\mathrm{pH}$ influence on $\delta^{18} \mathrm{O}$ values was minor.

Despite the greater depth of the occurrence of $C$. globularis stands (3-4 m) compared to $C$. tomentosa $(2-3 \mathrm{~m}), \delta^{18} \mathrm{O}$ values of water sampled from above the two species when they co-occurred in the same water bodies were very similar (Fig. 4). This indicates a well-mixed upper water column in all the lakes, at least to the water depth of $4 \mathrm{~m}$. Although no difference in $\delta^{18} \mathrm{O}$ values of ambient water above the charophyte stands of the two species was observed, $\delta^{18} \mathrm{O}$ values of the water within the charophyte stands could have been different. Therefore, in future studies, it would be useful to compare oxygen stable isotope values of both charophyte encrustations and water from above the macroalgae with $\delta^{18} \mathrm{O}$ values of the water from within the charophyte stands.
We ascribe the difference in $\delta^{18} \mathrm{O}$ values between C. tomentosa and C. globularis to the morphology of the two species studied. The stands of $C$. tomentosa, a charophyte with a large thallus and numerous branches, are relatively loose and freely penetrated by ambient water. In contrast, the dense stands formed by $C$. globularis are more isolated; thus, the depletion in ${ }^{18} \mathrm{O}$ of the water from within the charophytes may result from restricted mixing with the above waters, ${ }^{18} \mathrm{O}$-enriched by evaporation.

The second factor determining oxygen stable isotope composition of carbonates apart from $\delta^{18} \mathrm{O}_{\text {WATER }}$ is water temperature. Applying the well-known relation between carbonate $\delta^{18} \mathrm{O}$ values and water temperature, i.e., a $0.24 \%$ decrease with each $1{ }^{\circ} \mathrm{C}$ (Kim \& O'Neil, 1997), the $1.62 \%$ difference in $\delta^{18} \mathrm{O}$ values between $C$. tomentosa and $C$. globularis means that water temperature is higher by $6.75^{\circ} \mathrm{C}$ in the encrustation precipitation of the latter species $\left(\delta^{18} \mathrm{O}_{\mathrm{CARB}}\right.$ from Lakes Karskie Wielkie and Jasne was considered because of the co-occurrence of the two species and comparable $\delta^{18} \mathrm{O}_{\text {WATER }}$ above the stands of the two species, Online Resource 1). Considering the greater depth of $C$. globularis occurrence and restricted mixing with overlying waters, the opposite trend is expected. Thus, differences in water temperature failed to explain the shift between $\delta^{18} \mathrm{O}$ values in $C$. tomentosa and C. globularis.

Another factor that must be considered when studying stable isotope composition of biogenic carbonates is the so-called vital effect referring to the organism precipitating carbonates. In charophytes, ${ }^{18} \mathrm{O}$-depletion in encrustations relative to $\delta^{18} \mathrm{O}_{\text {WATER }}$ is linked with rapid $\mathrm{CaCO}_{3}$ precipitation on stems (McConnaughey, 1989; Andrews et al., 2004). $\delta^{18} \mathrm{O}$ values in C. tomentosa and C. globularis are in line with this observation (Fig. 3). The offset between $\delta^{18} \mathrm{O}_{\text {WATER }}$ and $\delta^{18} \mathrm{O}_{\mathrm{CARB}}$ increases with a higher rate of calcification resulting from intensive photosynthesis. Of the two species studied, C. tomentosa, the larger charophyte found at shallower sites where photosynthesis is more intensive due to higher light availability, is expected to have encrustations more ${ }^{18} \mathrm{O}$-depleted compared to $C$. globularis. This theoretical assumption disagrees with the available data and does not explain lower $\delta^{18} \mathrm{O}$ values in C. globularis (Online Resource 1). However, in laboratory studies, Sendra et al. (2010) found out that the charophytes can be affected by UV-B radiation, especially in long-term 
treatment. The UV-B radiation may decrease the photosynthesis rate. Consequently, $C$. tomentosa growing at shallower sites should precipitate carbonates, which are less ${ }^{18} \mathrm{O}$-depleted compared to $C$. globularis. On the other hand, Schmidt et al. (2010) and Sendra et al. (2010) did not find any statistically significant differences between charophyte individuals exposed to UV-B radiation compared to treatments without UV-B radiation, which, as they suggested, may result from adaptation to radiation. This aspect, however, requires further study performed in situ.

\section{Conclusions}

Encrustations of Chara tomentosa and Chara globularis were found to be ${ }^{18} \mathrm{O}$-depleted relative to $\delta^{18} \mathrm{O}$ values of water in all the studied lakes, in agreement with the effect expected during fast calcification. However, the rate of $\mathrm{CaCO}_{3}$ precipitation failed to explain lower $\delta^{18} \mathrm{O}$ values in $C$. globularis compared to $C$. tomentosa. The morphology of the two species, determining the density of charophyte stands (loose in $C$. tomentosa and dense in C. globularis) and, respectively, allowing or restricting water penetration into the studied stands, is regarded to be most likely to explain greater ${ }^{18} \mathrm{O}$-depletion of the latter species.

Nevertheless, the constant shift in stable isotope composition between the mean $\delta^{18} \mathrm{O}$ values of $C$. tomentosa and $C$. globularis encrustations and waters, $2 \%$ and $3.2 \%$, respectively, indicates that $\delta^{18} \mathrm{O}$ values of water are recorded by charophytes. However, this constant ${ }^{18} \mathrm{O}$ depletion in charophyte encrustations in relation to $\delta^{18} \mathrm{O}$ of water must be considered when applying charophyte $\delta^{18} \mathrm{O}$ values in paleolimnological studies. Problematic seems to be the different extent of ${ }^{18} \mathrm{O}$-depletion observed in the two species studied. Considering this outcome of our study stratigraphic change in $\delta^{18} \mathrm{O}$ values of the carbonates from a lake core can result from a change in the specific composition of charophytes and not from environmental factors, as expected.

Acknowledgements This paper utilizes results obtained during the research project N N304 042539 , which was supported financially by the Polish Ministry of Science and Higher Education between the years 2010 and 2013. Financial resources earmarked for statutory activities of the Department of Hydrobiology, Faculty of Biology, Adam Mickiewicz University are also acknowledged. All anonymous peer
Reviewers and Associated Editor are kindly acknowledged for their comments and suggestions, which helped to improve the manuscript.

Open Access This article is distributed under the terms of the Creative Commons Attribution 4.0 International License (http:// creativecommons.org/licenses/by/4.0/), which permits unrestricted use, distribution, and reproduction in any medium, provided you give appropriate credit to the original author(s) and the source, provide a link to the Creative Commons license, and indicate if changes were made.

\section{References}

Anadón, P., R. Utrilla \& A. Vázquez, 2000. Use of charophyte carbonates as a proxy indicators of subtle hydrological and chemical changes in marl lakes: example from the Miocene Bicorb Basin, eastern Spain. Sedimentary Geology 133: 325-347.

Andrews, J., P. Coletta, A. Pentecost, R. Riding, S. Dennis, P. F. Dennis \& B. Spiro, 2004. Equilibrium and disequilibrium stable isotope effects in modern charophyte calcites: implications for palaeoenvironmental studies. Palaeogeography, Palaeoclimatology, Palaeoecology 204: 101-114.

Apolinarska, K. \& D. Hammarlund, 2009. Multi-component stable isotope records from Late Weichselian and early Holocene lake sediments at Imiolki, Poland: Palaeoclimatic and methodological implications. Journal of Quaternary Science 24(8): 948-959.

Apolinarska, K., M. Pełechaty \& A. Pukacz, 2011. $\mathrm{CaCO}_{3}$ sedimentation by modern charophytes (Characeae): can calcified remains and carbonate $\delta^{13} \mathrm{C}$ and $\delta^{18} \mathrm{O}$ record the ecological state of lakes? a review. Studia Limnologica et Telmatologica 5: 55-66.

Apolinarska, K., M. Pełechaty \& D. Noskowiak, 2015. Differences in stable isotope compositions of freshwater snails from surface sediments of two Polish shallow lakes. Limnologica 53: 95-105.

Apolinarska, K., M. Pełechaty \& E. Pronin, 2016. Discrepancies between the stable isotope compositions of water, macrophyte carbonates and organics, and mollusc shells in the littoral zone of a charophyte-dominated lake (Lake Lednica, Poland). Hydrobiologia 768(1): 1-17.

Becker, D., L. Picot \& J.-P. Berger, 2002. Stable isotopes $\left(\delta^{13} \mathrm{C}\right.$ and $\delta^{18} \mathrm{O}$ ) of charophyte gyrogonites: example from the BrocheneFluh section (Late Oligocene-Early Miocene, Switzerland). Geobios 35: 89-97.

Bešta, T., J. Šafránkova, M. Pouzar, J. Novák \& K. Novákova, 2009. Late pleistocene-early holocene transition recorded in the sediments of a former shallow lake in the Czech Republic. Hydrobiologia 631: 107-120.

Blindow, I., A. Hargeby \& S. Hilt, 2014. Facilitation of clearwater conditions in shallow lakes by macrophytes: differences between charophyte and angiosperm dominance. Hydrobiologia 737: 99-110.

Coletta, P., A. Pentecost \& B. Spiro, 2001. Stable isotopes in charophyte incrustations: relationships with climate and 
water chemistry. Palaeogeography. Palaeoclimatology. Palaeoecology 173: 9-19.

Coplen, T. B., W. A. Brand, M. Gehre, M. Gröning, H. A. J. Meijre, B. Toman \& R. M. Verkouteren, 2006. New guidelines for $\delta^{13} \mathrm{C}$ measurements. Analytical Chemistry 78: 2439-2441.

Croft, W. N., 1952. A new Trochiliscus (Charophyta) from the Downtonian of Podolia. Bulletin of the British Museum (Natural History) 1: 189-220.

d'Obryn, K., J. Grabczak \& A. Zuber, 1997. Maps of isotopic composition of the Holocene meteoric waters in Poland. In Górski, J. \& E. Liszkowska (eds), Współczesne Problemy Hydrogeologii, Vol. 8. Wind Publications, Wroclaw: 331-333. (in Polish).

de Kluijver, A., P. L. Schoon, J. A. Downing, S. Schouten \& J. J. Middelburg, 2014. Stable carbon isotope biogeochemistry of lakes along a trophic gradient. Biogeosciences 11(22): 6265-6276.

Gałka, M. \& K. Apolinarska, 2014. Climate change, vegetation development, and lake level fluctuations in Lake Purwin (NE Poland) during the last $8600 \mathrm{cal}$. BP based on a highresolution plant macrofossil record and stable isotope data ( $\delta 13 \mathrm{C}$ and $\delta 180)$. Quaternary International 328-329: 213-225.

Gałka, M. \& M. Sznel, 2013. Late Glacial and Early Holocene development of lakes in northeastern Poland in view of plant macrofossil analyses. Quaternary International 292: 124-135.

Hammarlund, D., S. Björck, B. Buchardt, C. Israelson \& C. T. Thomsen, 2003. Rapid hydrological changes during the Holocene revealed by stable isotope records of lacustrine carbonates from Lake Igelsjön, southern Sweden. Quaternary Science Reviews 22(2-4): 353-370.

Hannon, G. E. \& M.-J. Gaillard, 1997. The plant-macrofossil record of past lake-level changes. Journal of Paleolimnology 18(1): 15-28.

Huon \& Mojon, 1994. Déséquilibre isotopique entre eau et parties calcifiées de Charophytes actuels (Chara globularis): résultats préliminaires. [Isotopic disequilibrium between water and calcified parts of Charophytes (Chara globularis): preliminary results] Comptes Rendus. Geosciences 318(2): 205-210. (in French).

Hutchinson, G. E., 1975. A Treatise on Limnology. Vol. 3: Limnological Botany. Wiley; Chapman and Hall. Ltd, New York; London.

Jańczak, J. (ed.), 1996. Atlas jezior Polski. Tom I. Jeziora Pojezierza Wielkopolskiego i Pomorskiego w granicach dorzecza Odry [Atlas of Polish lakes. Vol. I. Lakes of Pojezierze Wielkopolskie and Pomorskie lakelands within the Odra basin.]. Instytut Meteorologii i Gospodarki Wodnej, Bogucki Wydawnictwo Naukowe, Poznań (in Polish).

Kim, S.-T. \& J. R. O'Neil, 1997. Equilibrium and nonequilibrium oxygen isotope effects in synthetic carbonates. Geochimica et Cosmochimica Acta 61(16): 3461-3475.

Kołaczek, P., M. Gałka, M. Karpińska-Kołaczek \& M. Lutyńska, 2015. Late Pleniglacial and Late Glacial lakemire transformations in south-eastern Poland reflected in aquatic and wetland vegetation changes. Quaternary International 388: 39-50.
Kowalewski, G. A., R. Kornijów, S. McGowan, A. Kaczorowska, K. Bałaga, T. Namiotko, M. Woszczyk, M. Gąsiorowski \& A. Wasiłowska, 2016. Disentangling natural and anthropogenic drivers of changes in a shallow lake using palaeolimnology and historical archives. Hydrobiologia 767: 301-320.

Krause, W., 1981. Characeenals Bioindikatoren fur den Gewasserzustand. Limnologica 13(2): 399-418.

Królikowska, J., 1997. Eutrophication processes in a shallow, macrophytes dominated lake - species differentiation, biomass and the distribution of submerged macrophytes in Lake Łuknajno (Poland). Hydrobiologia 342-343: 411-416.

Kuczyńska-Kippen, N., 2001. Diurnal vertical distribution of rotifers (Rotifera) in the Chara zone of Budzynskie Lake, Poland. Hydrobiologia 446(447): 195-201.

Kufel, L. \& I. Kufel, 2002. Chara beds acting as nutrient sinks in shallow lakes - a review. Aquatic Botany 72: 249-260.

Lauterbach, S., A. Brauer, N. Andersen, D. L. Danielopol, P. Dulski, M. HÜLs, K. Milecka, T. Namiotko, B. Plessen, U. V. Grafenstein \& D. Participants, 2011. Multi-proxy evidence for early to mid-Holocene environmental and climatic changes in northeastern Poland. Boreas 40(1): 57-72.

Lehmann, M. F., S. M. Bernasconi, A. Barbieri, M. Simona \& J. A. McKenzie, 2004. Interannual variation of the isotopic composition of sedimenting organic carbon and nitrogen in Lake Lugano: A long-term sediment trap study. Limnology and Oceanography 49(3): 839-849.

Leng, M. J. \& J. D. Marshall, 2004. Palaeoclimate interpretation of stable isotope data from lake sediment archives. Quaternary Science Reviews 23: 811-831.

Li, X. \& W. Liu, 2011. Effect of preservation on the $\delta^{13} \mathrm{C}$ value of dissolved inorganic carbon in different types of water samples. Isotopes in Environmental and Health Studies 47(3): 379-389.

Martin, G., K. Torn, I. Blindow, H. Schubert, R. Munsterhjelm \& C. Henricson, 2003. Introduction to charophytes. In H. Schubert \& I. Blindow (eds) Charophytes of the Baltic Sea. The Baltic Marine Biologists Publications No. 19. Gantner. Ruggell: 3-14.

McConnaughey, T., 1989. ${ }^{13} \mathrm{C}$ and ${ }^{18} \mathrm{O}$ isotopic disequilibrium in biological carbonates: I. Patterns. Geochimica et Cosmochimica Acta 53: 151-162.

McConnaughey, T., 1997. Acid secretion, calcification, and photosynthetic carbon concentrating mechanisms. Canadian Journal of Botany 76: 1119-1126.

McCrea, J. M., 1950. The isotopic chemistry of carbonates and a paleotemperature scale. The Journal of Chemical Physics 18: 849-857.

Pełechata, A., M. Pełechaty \& A. Pukacz, 2016. Factors influencing cyanobacteria community structure in Chara-lakes. Ecological Indicators 71: 477-490.

Pełechaty, M., A. Pełechata \& A. Pukacz, 2007. Flora i roślinność ramienicowa na tle stanu trofii jezior Pojezierza Lubuskiego (środkowo-zachodnia Polska). [Charophyte flora and vegetation against the background of the trophy state of Lubuskie Lakeland. mid-Western Poland].Uniwersytet im. Adama Mickiewicza w Poznaniu. Bogucki Wydawnictwo Naukowe. Poznań (in Polnish). 
Pełechaty, M., K. Apolinarska, A. Pukacz, J. Krupska, M. Siepak, P. Boszke \& M. Sinkowski, 2010. Stable isotope composition of Chara rudis incrustation in Lake Jasne, Poland. Hydrobiologia 656: 29-42.

Pełechaty, M., A. Pukacz, K. Apolinarska, A. Pełechata \& M. Siepak, 2013. The significance of Chara vegetation in the precipitation of lacustrine calcium carbonate. Sedimentology 60(4): 1017-1035.

Pełechaty, M., J. Ossowska, A. Pukacz, K. Apolinarsk \& M. Siepak, 2015. Site-dependent species composition, structure and environmental conditions of Chara tomentosa L. meadows, western Poland. Aquatic Botany 120: 92-100.

Pentecost, A., 1984. The growth of Chara globularis and its relationship to calcium carbonate deposition in Malham Tarn. Field Studies 6: 53-58.

Pentecost, A., J. E. Andrews, P. F. Dennis, A. Marca-Bell \& S. Dennis, 2006. Charophyte growth in small temperate water bodies: Extreme isotopic disequilibrium and implications for the paleoecology of shallow marl lakes. Palaeogeography Palaeoclimatology Palaeoecology 240: 389-404.

Pronin, E., M. Pełechaty, K. Apolinarska, A. Pukacz \& M. Frankowski, 2016. Sharp differences in the $\delta^{13} \mathrm{C}$ values of organic matter and carbonate encrustations but not in ambient water DIC between two morphologically distinct charophytes. Hydrobiologia 773(1): 177-191.

Pukacz, A., M. Pełechaty, M. Frankowski, A. Kowalski \& K. Zwijacz-Koszałka, 2014. Seasonality of water chemistry, carbonate production and biometric features of two species of Chara in a shallow clear water lake. The Scientific World Journal. https://doi.org/10.1155/2014/167631.

Pukacz, A., M. Pełechaty \& M. Frankowski, 2016a. Depth-dependence and monthly variability of charophyte biomass production: Consequences for the precipitation of calcium carbonate in a shallow Chara-lake. Environmental Science and Pollution Research 23: 22433-22442.

Pukacz, A., M. Pełechaty, M. Frankowski \& E. Pronin, 2016b. Dry weight and calcium carbonate encrustation of two morphologically different Chara species: a comparative study from different lakes. Oceanological and Hydrobiological Studies 46(3): 377-387.

Rodrigo, M. A., A. García \& A. R. Chivas, 2016. Carbon stable isotope composition of charophyte organic matter in a small and shallow Spanish water body as a baseline for future trophic studies. Journal of Limnology 75(2): 226-235.

Rutkowski, J., K. Król \& J. Szczepańska, 2007. Lithology of the profundal sediments in Słupiańska Bay (Wigry Lake, NE Poland) - introduction to interdisciplinary study. Geochronometria 27: 47-52.
Schmidt, E. C., M. Maraschin \& Z. L. Bouzon, 2010. Effects of UV-B radiation on the carragenophyte Kappaphycus alvarezii (Rhodophyta, Gigartinales): changes in ultrastructure, growth and photosynthetic pigments. Hydrobiologia 649: 171-182.

Sendra, J., F. Rubio \& M. A. Rodrigo, 2010. Are there any effects of enhanced UV-B radiation on Chara polyacantha and Nitella hyalina under laboratory conditions? Rostocker Meeresbiologische Beiträge 23: 7-20.

Skrzypek, G., A. Mydłowski, S. Dogramaci, P. Hedley, J. J. Gibson \& P. F. Grierson, 2015. Estimation of evaporative loss based on the stable isotope composition of water using Hydrocalculator. Journal of Hydrology 523: 781-789.

Słowiński, M., I. Zawiska, F. Ott, A. M. Noryśkiewicz, B. Plessen, K. Apolinarska, M. Rzodkiewicz, D. J. Michczyńska, S. Wulf, P. Skubała, J. Kordowski, M. Błaszkiewicz \& A. Brauer, 2017. Differential proxy responses to late Allerod and early Younger Dryas climatic change recorded in varved sediments of the Trzechowskie palaeolake in Northern Poland. Quaternary Science Reviews 158: 94-106.

Stuiver, M., 1970. Oxygen and carbon isotope ratios of freshwater carbonates as climatic indicators. Oceans and Atmospheres 75: 5247-5257.

Szymanek, M., K. Bińka \& J. Nitychoruk, 2016. Stable ${ }^{18} \mathrm{O}$ and ${ }^{13} \mathrm{C}$ isotope records of Viviparus diluvianus (Kunth, 1865) shells from Holsteinian (MIS 11) lakes of eastern Poland as palaeoenvironmental and palaeoclimatic proxies. Boreas 45(1): 109-121.

Urbaniak, J., 2010. Estimation of carbonate and element content in Charophytes - methods of determination. Polish Journal of Environmental Studies. 19(2): 413-417.

Von Grafenstein, U., U. Eicher, H. Erlenkeuser, P. Ruch, J. Schwander \& B. Ammann, 2000. Isotope signature of the Younger Dryas and two minor oscillations at Gerzensee (Switzerland): palaeoclimatic and palaeolimnologic interpretation based on bulk and biogenic carbonates. Palaeogeography, Palaeoclimatology, Palaeoecology 159: 215-229.

Wade, I. M., 1990. The colonization of disturbed freshwater habitats by Characeae. Folia Geobotanica et Phytotaxonomica 25(3): 275-278.

Woszczyk, M., N. Grassineau, W. Tylmann, G. Kowalewski, M. Lutyńska \& A. Bechtel, 2014. Stable C and N isotope record of short term changes in water level in lakes of different morphometry: Lake Anastazewo and Lake Skulskie, central Poland. Organic Geochemistry 76: 278-287. 